\title{
Option Agreement and the Promise to Contract as Established in the NeW Romanian Civil Code
}

[La regulación del contrato de opción y de la promesa de contrato en el nuevo 'Código Civil' rumano]

\author{
URS ILIE* \\ "Dimitrie Cantemir" Christian University, Bucharest, Romania
}

\begin{abstract}
In the Romanian private law, the option agreement is not a unilateral promise to sell, neither a variety of the unilateral promise to sell, but a contract with an option right. The option agreement is a contract with an option right, under which one of the parties shall undertake to stick to its offer to enter into a given contract, as he has already consented to that, whereas the other party, the beneficiary, shall be entitled to accept or refuse the offer; the use of the acceptance right is enough to enter into that contract. This article examines the status to which the
\end{abstract}

\section{Resumen}

En el Derecho privado rumano, el contrato de opción no es una promesa unilateral de venta, ni una variedad de la promesa unilateral de venta, sino un contrato con un derecho de opción. El contrato de opción es un contrato con un derecho de opción, en virtud del cual una de las partes se compromete a adherirse a su oferta de celebrar un contrato determinado, para el que ya ha dado su consentimiento, mientras que la otra parte, el beneficiario, tendrá derecho para aceptar o rechazar la oferta; el ejercicio del derecho de aceptación es suficiente

RECIBIDo el 29 de noviembre de 2012 y ACEPTADo el 22 de abril de 2013

* Professor at Faculty of Law Cluj-Napoca, "Dimitrie Cantemir" Christian University. Adress: Str. Calea Dorobantilor Nr. 74, bloc Y9, scara 2, ap. 27, postal code 400609, Cluj-Napoca, Romania. E-mail:dr_ursilie@yahoo.com 
contract is subject jn the new Romanian Civil Code.

\section{KEYWORDS}

Option agreement - Promise to contract - New Romanian Civil Code. para perfeccionar el contrato. En este trabajo se estudia el estatuto al que se sujeta dicho contrato en el nuevo Código Civil rumano.

Palabras clave

Acuerdo de opción - Promesa de contrato - Nuevo Código Civil rumano.

\section{Introduction.}

As of 2004 and after the accession of Romania to the European Union (January $1^{\text {st }}$ 2007), a new Civil Code started to be drafted in order to meet current social and legal requirements in Romania ${ }^{1}$.

Consequently, the new Romanian Civil Code, in force since October $1^{\text {st }}$ 2011, was adopted by the Statute Nr. 287 of July $17^{\text {th }} 2009^{2}$. Among the novelties existing in the new Civil Code, we mention the regulation of the "the option agreement" and of "the promise to contract".

As far as the option agreement is concerned, there are contradictory points of view regarding its legal nature: according to some authors, the option agreement is a unilateral promise to sell or a type of the promise to sell; according to other authors, the option agreement is different from the promise to contract.

That is why we shall try to study the institutions in question.

\section{Regulation. Notion}

Within the meaning of article 1278 Rom.CC.:

"(1) When two parties agree that one of the parties should stick to its own declaration of will, whereas the other party should have the right to accept or revoke it, that declaration is considered to be an irrevocable offer and produces the effects stipulated under article 1191./ (2) In case the parties have not agreed upon a time for acceptance, this shall be established by the Court via interlocu-

${ }^{1}$ In order to elaborate the new Romanian Civil Code, a number of templates have been used, taking into account especially the Civil Code of the province of Quebec, Canada, in force since 1994. Further sources of inspiration were the civil codes from France, Italy, Spain, Switzerland, Germany and Brazil. A large part of the provisions of the old 1864 Romanian Civil Code are also to be found in the new Civil Code.

${ }^{2}$ Published in the "Official Gazette of Romania" Nr. 511 of July 24th 2009, amended by the implementation Statute Nr. 71/2011, published in the "Official Gazette of Romania” Nr. 696 of September 302011. 
tory order, by citing the parties. (3) The option agreement must contain all the elements of the contract the parties are about to conclude, so that this contract can be concluded by acceptance on the part of the beneficiary of the option./ (4) The contract shall be concluded when the option is put into practice, that is when the beneficiary accepts the declaration of will of the other party, under the conditions agreed upon under the agreement./ (5) Both the option agreement and the declaration of acceptance shall be concluded in the legally stipulated form for the contract the parties are about to enter into".

Based on the above mentioned legal provisions, we consider that the option agreement is a "contract with an option right", under which one of the parties shall undertake to stick to its offer to enter into a given contract, as he has already consented to that, whereas the other party, the beneficiary, shall be entitled to accept or refuse the offer; the use of the acceptance right is enough to enter into that contract.

\section{The option agreement and the offer to enter into a contract.}

According to the above mentioned legal provisions, the option agreement has similarities with the "offer to enter into a contract". Consequently, just like the offer to enter into a contract ${ }^{3}$, the option agreement shall contain all the elements required for the conclusion of the contract that the parties are about to enter into. Similarly, an option agreement shall be entered into by simply accepting the declaration of will of the other party, whereas that declaration is considered "[...] to be an irrevocable offer and produces the effects stipulated under article 1191"4.

Although article 1278 (1) prescribes that: "[...] that declaration is considered to be an irrevocable offer and produces the effects stipulated under article 1191", the option agreement is not just a simple offer to enter into a contract.

Consequently, the offer to enter into a contract is a unilateral expression of will that is a unilateral legal transaction, whereas the option agreement ${ }^{5}$ is

${ }^{3}$ Within the meaning of Article 1188 (1) RomCC.: "A proposal becomes an offer to enter into a contract in case it consists of all the necessary elements for concluding the contract and expresses the intent of the offeree to undertake obligations in case such offer shall be accepted by the recipient".

${ }^{4}$ According to Article 1191 RomCC.: "(1) The offer is irrevocable for how long its author undertakes to keep it. It is also irrevocable every time it may be considered as such based on the agreement between the parties, the practices they are used to, the negotiations, the content of the offer or the customary practices. (2) The declaration to revoke an irrevocable offer produces no effect whatsoever".

${ }^{5}$ Etymologically, "pact/agreement" comes from Latin, from "pactum", meaning (written) understanding between parties, accord, convention: see DEX ( $2^{\text {nd }}$ edition, Bucharest, Univers Encyclopedic Publishing House, 1996), p. 738. 
a bilateral contract ${ }^{6}$, legal transaction, as it is all about an agreement between parties. To this purpose, based on the provisions of article 1278 (1), "two parties agree", meaning they come to an understanding or into accord (contract). The parties involved "agree" that one of them should stay obliged by his own declaration of will (irrevocable offer) and the other party should have the right to "accept" or "refuse" it. As a consequence, the option agreement is the consent of both parties.

Secondly, the offer is made publicly, whereas the option agreement is only made to the benefit of a certain individual, the so called beneficiary, who agrees that the right (to accept or refuse the offer) should be made to his advantage ${ }^{7}$.

Taking these arguments into consideration, it is unanimously agreed that the option agreement is a contract, not a simple offer to enter into a contract.

The option agreement is a unilateral contract because only one of the contracting parties undertakes obligations, respectively the party agreeing to stay obliged his own declaration of will. The other contracting party (the beneficiary) undertakes no obligation when the agreement is entered into. He only accepts to be the recipient of the offer (the declaration of will of the other party); his acceptance should by no means be mistaken with the "application of the option" (to accept or refuse the offer). The beneficiary of the option may freely accept or refuse the offer. Only if he accepts the offer, the contract in question shall be entered into, thus deriving obligations on his part.

\section{The content of the option agreement.}

According to article 1278 (3), the option agreement must contain all the elements of the contract the parties are about to conclude, so that this contract can be concluded by acceptance on the part of the beneficiary of the option. For example, the option agreement related to a sales contract shall make reference to the item to be sold and its price.

Likewise, within the meaning of the provisions of article 1668 (1) of the new Civil Code, as far as the option agreement regarding a sales contract related to a given individual item is concerned, the item in question is not to be used between the date the agreement has been made and the date the option is put into practice or, as the case may be, the date of expiry of the option. This

${ }^{6}$ See Moțiu, F., Civil contracts in the new Civil Code (Bucharest, Wolters Kluwer Publishing House, 2010), p. 26; STĂnciulescu, L., Civil Law Lectures. Contracts (Bucharest, Hamangiu Publishing House, 2012), p. 106.

${ }^{7}$ See Moțiu, F., cit. (n. 6), p. 26. 
leads to the conclusion that the option agreement regarding a sales contract includes a legal and temporary perpetuity clause of that item.

\section{The form of the option agreement.}

According to the provisions of article 1278 (5), both the option agreement and the declaration of acceptance of the beneficiary shall be concluded in the legally stipulated form for the contract the parties are about to enter into. For example, considering the contract must be drafted in authenticated form, the option agreement and the declaration of acceptance, too, shall be drafted in authenticated form.

In cases when the option agreement has in view property rights to be registered in the real estate/land register, the right to option of the beneficiary shall also be recorded in the real estate register [article 1668 (2) RomCC.]; this formality shall be done by the notary public. The right to option shall be invalidated by default if, until the expiry of the option, no declaration to put into practice the option has been recorded accompanied by the proof that the other party has been notified accordingly [article 1668 (3) RomCC.].

\section{The conclusion of the contract.}

According to article 1278 (4), the contract is entered into when the beneficiary puts into practice the option, that is he accepts the declaration of will (offer) of the other party, under the conditions agreed upon.

The declaration of acceptance of the beneficiary shall be made within the period of time agreed upon by the parties or by the Court and shall be communicated to the other party. If, until the expiry of the option, no declaration of acceptance has been made, the agreement becomes void; nonetheless, should the party obliged by his declaration of will accept to conclude the contract, it is still valid, as the party declared null and void the deadline.

The declaration of acceptance of the offer is a unilateral act of the beneficiary who must be in mental health at the time the declaration is made.

When the beneficiary puts into practice the option, that is he accepts the offer, the contract comes permanently into force, no other formality being necessary; this is when the beneficiary undertakes obligations as well. For example, in case of an option agreement regarding a sales contract related to a given individual item, the beneficiary becomes the holder of the property right after he has paid the price.

The conclusion of the contract does not generate retroactive effects because the beneficiary failed to undertake any obligations until the date of the option agreement; the beneficiary only agreed that the other party should stay obliged by the declaration of will, he himself preserving his freedom of option 
(to accept or refuse the offer). Should the beneficiary refuse the declaration of will (offer) of the other party, that contract cannot be entered into.

On the other hand, should the beneficiary keep silent all along the option period of time, this does not mean that he accepted the offer, as the declaration of acceptance is an express consent.

Once the contract has been entered into, both the party who stayed obliged to the conclusion of the option agreement as well as the beneficiary shall have the obligation to execute the contract. Should one of the parties fail to fulfill his obligations, they will be held liable.

\section{Legal nature of the option right of the beneficiary.}

According to the current Romanian legal literature, the beneficiary's right of option is a debt item because it derives from the convention between two parties having an obligation-based relation in which one party is the creditor and the other party is the debtor ${ }^{8}$.

In our opinion, the beneficiary's right of option is not a debt item because, before exercising his right, the beneficiary is not a creditor for the other party. The beneficiary of the option agreement is only entitled to accept or refuse the offer of the other party. Only after the beneficiary has exercised his right of option -he has accepted the offer- after the conclusion of the contract, the beneficiary becomes the titular of a benefice or a title in relation to the other party. Under the circumstances, we consider that the beneficiary's right of option is a potestative right ${ }^{9}$, granting him the power to enter into a contract by his own will (unilateral).

\section{Area of application of the option agreement.}

The new Civil Code expressly refers to the option agreement in relation to a sales contract (article 1668). However, based on the provisions of article 1278 , basically, the "option agreement" can be applied in any type of contract, provided that both the agreement and the declaration of acceptance of the

\footnotetext{
${ }^{8}$ Ibíd., p.26.

${ }^{9}$ In the French legal literature where the unilateral promise to sell is called "option agreement", the nature of the beneficiary's personal right is ambiguous. Traditionally, it is considered to be a debt item against the promisor. However, according to some authors, it is actually a potestative right: the power to buy by his unilateral will. See Malaurie, P. - Aynès, L. - Gautier, P.-Y., Special contracts (Bucharest, Wolters Kluwer Publishing House, 2009), p. 69; BOYER, L., Les promesses synallagmatiques de vente, in Revue Trimestrelle de Droit Civil, 47 (1949), pp. 1 and foll., especially $\mathrm{N}^{\circ} 28$, p. 27; NaJjar, I., Le droit d'option à l' étude du droit potestatif et de l acte unilatérale (Paris, L.G.D.J., 1967), p.137 and foll.
} 
offer should be concluded in the legally stipulated form for the contract the parties are about to enter into.

\section{The option agreement and the promise to enter into a contract in the} Romanian private law.

According to a recent author of the Romanian legal literature, the option agreement is nothing else than a unilateral promise to sell. In his opinion, in the Romanian legal context, it is impossible to legally differentiate between the unilateral promise to sell and the option agreement. There is only one difference and it relates to their legal regime -their effects- which is not identical. Thus, as far as the unilateral promise to sell is concerned, the beneficiary may ask the Court to give an order that is equivalent to a contract, within the meaning of article 1279 (3) and article 1669 (1) RomCC. On the contrary, the sales contract under the option agreement is entered into only after the beneficiary has accepted the declaration of will/offer of the other party (exercising the option) under the conditions agreed upon. Consequently, the legal regime favors the beneficiary of the option agreement who only to express his needs will for the contract to be concluded. Should the promisor oppose the execution of the contract, the Court shall declare/ establish the conclusion or non-conclusion of the contract ${ }^{10}$.

In the opinion of another author, the option agreement is a variety of the promise to sell which is subject to a simple potestative condition that is it depends on the will of the person in charge of acceptance, according to which he is willing to buy the item ${ }^{11}$. Another author states that, since only one of the parties (promisor) expressly undertakes the obligation to sell and considering that it is equally possible that the sale should or should not be performed, the option agreement has the features of a variety of the unilateral promise to sell, thus coming to the conclusion that "the option agreement is basically a unilateral promise to sell"12.

Eventually, previous to the implementation of the new Romanian Civil Code, under the influence of the French doctrine, a Romanian author said that the unilateral promise and the option agreement are one and the same thing; the unilateral promise ows its originality and specificity to the fact that basically, in order for the sale to be fulfilled, it is enough for the beneficiary to agree on the offer (accepting the offer to sell of the promisor), as the promisor, on his part, has already expressed his will to sell in favor of

\footnotetext{
${ }^{10}$ See Moțiu, F., cit. (n. 6), p. 27.

${ }^{11}$ See Florescu, D., Civil contracts (Bucharest, Universul Juridic Publishing House, 2011), p. 23.

${ }^{12}$ See StĂnciulescu, L., cit. (n. 6) p. 107.
} 
the beneficiary; that is why the unilateral promise to sell is commonly used under the name of option agreement ${ }^{13}$.

In our opinion, in the context of the new Romanian Civil Code, the option agreement and the unilateral promise to sell are two distinct legal institutions, with a different legal regime.

In order to better understand our arguments, we need to briefly enumerate below the fundamental coordinates of the unilateral promise to enter a contract, as the unilateral promise to sell is just a variety of it.

The old 1864 Romanian Civil Code, in force until October the $1^{\text {st }}$ 2011, did not regulate the option agreement nor the unilateral promise to enter into a contract, the latter being the result of the legal doctrine and practice. The unilateral promise to enter into a contract has been defined as "the convention according to which one of the parties, hereinafter called the promisor, undertakes the obligation towards the other party, hereinafter called the beneficiary, to enter in the future, at the request of the beneficiary, into a contract whose fundamental content is currently subject to the promise to enter into the contract"14.

According to the traditional perspective in our private legislation, the unilateral promise to enter into a contract generates a unilateral obligationbased relation stipulating the obligation of the promisor to enter into the contract he promised to and the right of the beneficiary to request or not the conclusion/formation of that contract ${ }^{15}$.

The obligation of the promisor to enter into the contract is an obligation to do $\mathrm{so}^{16}$ and it is valid for as long as it was established between the parties; in case no deadline has been established, it shall be in force until the fulfillment of the general prescription time under the common law ${ }^{17}$, respectively three

${ }^{13}$ See Chirică, D., Civil Law Treaty. Special Contracts, I: Sale and Exchange (Bucharest, C.H.Beck Publishing House, 2008), p. 148-149.

${ }^{14}$ See Mureșan, M., Civil Law Dictionary, by M. Costin, M. Mureșan, V. Ursa (Bucharest, Scientific and Encyclopedic Publishing House, 1988), p. 408-409. In the legal practice it was decided that "a promise to enter a contract, whose practical utility explains its ongoing use, is a prior agreement between parties based on which they undertake the obligation to enter into a contract in the future" (To this end, see the Supreme Court of Justice, civil department, Decision Nr. 276 of February the 26th 1970, in MinUȚĂ, I. G., Collection of Legal Cases in Civil Matters of the High Court and of other Courts in the period of Time 1969-1975 (Bucharest, Scientific and Encyclopedic Publishing, 1976), p. 131.

${ }^{15}$ See Pop, L., Civil Law Treaty. Obligations, II: The Contract (Bucharest, Universul Juridic Publishing House, 2009), pp. 219-220.

${ }^{16}$ Ibíd., p. 220. For the same purpose, see the Supreme Court of Justice, Civil Department, Decision Nr. 1140 of May 20th 1972, in MinuțĂ, I.G., cit. (n. 14), p. 131.

${ }^{17}$ High Court of Cassation and Justice, Commercial Department, Decision Nr. 
years since the promise has been made; when the extinctive prescription is due, a natural obligation shall be generated ${ }^{18}$.

The unilateral promise to enter into a contract is valid concluded solo consensus, because it does not produce the effects of the contract promised, but it only aims at anticipating its content and at guaranteeing its future conclusion under the form stipulated by law ${ }^{19}$.

If, at the request of the beneficiary -formulated within the validity time of the unilateral promise to enter into a contract- the promisor unreasonably refuses to enter into the contract, the beneficiary is entitled to claim compensation for all damage caused by failure to fulfill the obligation to "enter into contract", namely "to do so", undertaken by the promisor. Exceptionally, in the situations expressly stipulated under law, the beneficiary of the promise can request and obtain the enforcement in kind of the obligations of the promisor, by means of a Court order which is equivalent to the promised contract $^{20}$.

The analysis of the unilateral promise to enter into a contract is subject, in the Romanian legislation -in the doctrine and in the case-law- almost exclusively to the sale contract territory ${ }^{21}$. In the case-law, the unilateral promise to enter into a contract is most of the times a unilateral promise to sell ${ }^{22}$. The unilateral promise to sell was strongly developed and frequently implemented during the Communism (1945-1989) ${ }^{23}$ because of the serious

1819 of May 11th 2011, in the magazine Dreptul, 8 (2012), p. 252.

${ }^{18}$ See NicolaE, M., Extinctive Prescription (Bucharest, Rosetti Publishing House, 2004), p. 584-585.

As for the legal practice, see the Supreme Court of Justice, Civil Department, Decision Nr. 2149 of December 4th 1971, in Minuță, I. G., cit. (n. 14), p. 130-131.

${ }^{19}$ Pop, L., cit. (n. 15), p. 220.

${ }^{20}$ Ibidem. Also see the Supreme Court of Justice, Civil Department, the closure from May 24th 1969, in Minuță, I. G., cit. (n. 14), p. 130; ANDrei, D. - RoneA Avram, M. - Dumitrache, B., The Obligations of the Promisor Seller and their Enforcement, in the magazine Dreptul, 3 (1995), p. 25-36.

${ }^{21}$ See Pop, L., cit. (n. 15), p. 219.

${ }^{22}$ For the unilateral promise to sell, see: Albu, I., Civil law. The Contract and Contractual Obligation (Cluj-Napoca, Dacia Publishing House, 1994), p. 10-12; CHIRICĂ, D., Civil Law, Special Contracts (Bucharest, Lumina Lex Publishing House, 1997), pp. 18-21; Safta-Romano, E., Civil Law. Obligations (Focşani, Neuron Publishing House, 1994), p. 57-59. It is also possible to enter into a unilateral promise to buy; the unilateral promise to buy is symmetrically opposed to the unilateral promise to sell, still it is less commonly found in the case-law.

${ }^{23}$ See Ionașcu, A. -Mureșan, M. - Costin, M ., The Contribution of Case-Law to the Development of the Principles of the Romanian Civil Law (Bucharest, The Publishing House of the Academy, vol. I, 1973, vol. 2, 1978); BÂrsan, C., Legal Regime of Real Estate Assets (Bucharest, Scientific and Encyclopedic Publishing House, 1983); 
constraints and multiple conditions affecting the sale of real estate items after $1950^{24}$.

According to the Romanian legal literature, based on a unilateral promise to sell, the owner of an item promises an individual to sell that item, on the condition that he shall later on give his consent to buy, usually within an established period of time ${ }^{25}$. In other words, the unilateral promise to sell is a contract based on which a person, called "promisor", undertakes an obligation to sell in the future a certain item to another person, called "beneficiary", should the latter express his consent to buy $i^{26}$.

The unilateral (as well as the bilateral) promise to sell is also known as "promissory agreement" (a pre-existing contract) ${ }^{27}$. It is a unilateral preexisting contract; one of the parties is obliged (the obligation to do) towards

Vurdea, I. C. Bîrsan, C. - Stoica, V., The Evolution of Legislation Regarding the Circulation of Buildings, in the magazine Dreptul, 6 (1990), pp. 38-52; CHIRICĂ, D., The Consequences of the Post-Revolutionary Legislative Amendments upon the Circulation of Privately-Owned Land, in the magazine Dreptul, 6 (1991), pp. 22-32; MureșAn, M., Consequences of the Repealed Law 58/1974 upon the Promissory Contracts to Sell Real Estate Assets, in the magazine Dreptul, 7-8 (1991), pp. 91-100; Pătulea, V., The Enforcement of Civil Law Related to the Alienation of Real Estate Assets, in the magazine Dreptul, 11 (1992), pp. 29-30; Chelaru, E., Aspects Related to the Legal Circulation of Privately-Owned Land, in the magazine Dreptul, 9 (1993), pp. 22-26; SAFTA-RomANo, E., Legal Regime of Promissory Contracts in Relation to the Alienation of Real Estate Assets After the Repealing of Decree Nr. 144/1958, in the magazine Dreptul, 9 (1993), pp. 27-33; DîrJan, T., The Pre-Existing Sale Contract, in the magazine Dreptul, 3 (2000), pp. 55-62; Popa, I. - Dumitrache, B., The Pre-Existing Sale Contract and the Synallagmatic Promise to Sell-Buy, LuLĂ, I. - HanteA, D., Debates on the Synallagmatic Promise to Sell-Buy Land, in the magazine Dreptul, 9 (2003), pp. 67-78.

${ }^{24}$ For example, Decree Nr. 151/1950, Decree Nr. 221/1950, Decree Nr. 144/1958, Law Nr. 19/1968, Statute Nr. 58/1974 and Statute Nr. 59/1974.

${ }^{25}$ See DeAK, F., Civil Law Treaty. Special Contracts ( $3^{\text {rd }}$ edition, updated and completed, Bucharest, Universul Juridic Publishing House, 2001), p. 23.

${ }^{26}$ See Urs, I., Civil Law. Special Contracts, I: Sale, Exchange and Donation (ClujNapoca, Risoprint Publishing House, 2010), p. 11. For a different definition, similar to the definition of the option agreement in the French legislation, see CHIRICĂ, D., Civil Law Treaty. Special Contracts, I: Sale and Exchange (Bucharest, C.H.Beck Publishing House, 2008), p. 159.

${ }^{27}$ See Mureșan, M., Civil Law. Special Contracts. Academic Courses (Cluj-Napoca, Cordial Lex Publishing House, 1999), pp. 129-130, DeAK, F., cit. (n. 25), p. 24; According to the established case-law, the promise, as a contract not regulated by law, shall follow in respect of the mechanism of formation of the agreement the general rules applicable tu contracts. See the Supreme Court of Justice, civil department, Decisions Nr. 124 of January 26th 1971; Nr. 1456 of June 7th 1973; Nr. 1164 of May 24th 1972; Nr. 1909 of November 9th 1971; Nr. 2289 of December 21st 1971, all in I.G.Minuță, op.cit. (n. 14), p. 131-133). For the same purpose, another decision stated that "the pre-existing contract must meet all the general validity requirements 
the other party to sell in the future a certain item, whereas the beneficiary of the promise may choose between buying it ir not.

As shown in the legal literature ${ }^{28}$ and in the case-law ${ }^{29}$, the promise to sell, accepted under this contractual reservation, is undoubtedly a contract; however it is not a sale, being distinct from it, therefore it does not produce the effects of a sale. The promise to sell does not mean the transfer towards the beneficiary of a real right upon the asset; the obligation of the promisor as "an obligation to do" can only generate a claim for the other party ${ }^{30}$.

As for the rest, the unilateral promise to sell has been subject to the above mentioned traditional legal regime of the unilateral promise to enter a contract.

The new Civil Code expressly regulates the promise to enter a contract. Consequently, within the meaning of article 1279:

"(1) The promise to enter into a contract shall contain all the clauses of the contract promised, otherwise the parties would be unable to fulfill their promise./ 2) For failure to fulfill a promise, the beneficiary is entitled to claim compensation./ (3) Likewise, should the promisor fail to enter into the contract he promised, the Court, at the request of the party who has fulfilled his obligations, can issue an order which can replace the contract if the type of the contract allows for this and the legal requirements for the contract validity are fulfilled. The provisions of thisparagraph are not applicable in case of the promise to enter into a real contract, unless otherwise stipulated by the law. (4) The convention based on which the parties undertake the obligation to negotiate with a view to concluding or altering a contract is not a promise to enter a contract".

Considering the provisions of article 1279, we believe that the promise to enter into a contract preserved the traditional legal regime, namely it is basically as it was created by the Romanian doctrine and case-law before the entry into force of the new Romanian Civil Code. Based on paragraphs (2) and (3), it is without a doubt that the obligation of the promisor still is "an obligation to do", to enter into the contract he promised.

of legal acts [...]" (See the Supreme Court of Justice, civil department, Decision Nr. 2339/1993, in the magazine Dreptul, 8 (1994), p. 79).

${ }^{28}$ See Deak, F., cit. (n. 25), p. 23.

${ }^{29}$ See Turianu, C., Special Civil Contracts. Established Case-Law (Bucharest, All Beck Publishing House, 2000), p. 81; the Supreme Court decided that "the pre-existing contract, as a legal act, is a special convention, which is different from the future sale document. It is not a sale contract, it only generates the obligation of the parties to fulfill all the operations related to the conclusion of the contract [...]" (the Supreme Court of Justice, civil department, Decision Nr. 952 of April 7th 1973, in Minuță, I. G., cit. (n. 14), p. 133).

${ }^{30}$ The High Court of Cassation and Justice, commercial department, Decision Nr. 1819 of May 11th 2011, in Dreptul, 5 (2012), p. 229. 
Back to our point of view, according to our legislator, the option agreement is not a unilateral promise, and consequently, cannot be a unilateral promise to sell, for the following reasons.

In Romanian, "promise" means "commitment of a person to do something", whereas to promise means "to undertake the obligation to do something" ${ }^{11}$; legally, "promise" has the same meaning; consequently, in the case of the option agreement, the person undertaking the obligation to stay obliged to his own declaration of will is not a promisor because he does not undertake the obligation to do something (to enter into the contract he promised); as far as he is concerned, that contract has already been entered into since the day of the option agreement, as he has fully and irrevocably consented to the conclusion of the contract; as a result, he has nothing else to do in the future for the conclusion of that contract; however, in the case of the unilateral promise, the promisor has the obligation to do: he is going to do something, he is going to enter into the contract he promised; as far he is concerned, the contract has not been entered into on the day he gave his promise. In the Romanian legal literature, "the option agreement is not to be mistaken for the promise to enter into a contract (the pre-existing sale contract). The unilateral or bilateral promise to enter into a contract generates an obligation on part of the parties involved to conclude in the future the planned contract, whereas the option agreement generates an obligation to firmly stick to the proposal already made once it has been accepted; the acceptance is enough for the conclusion of the contract..."32.

Secondly, the new Civil Code regulates individually the option agreement (article 1278) and the promise to enter into a contract (article 1279). Likewise, under the sale contract, chapter I, section I, the new Civil Code makes reference to "the option agreement related to the sale contract and the promise to sell", thus proving that the legislator sees them as two distinct institutions.

Thirdly, the option agreement has a wider area of application as it may basically refer to any type of contract. On the other hand, the option agreement regarding a sale contract may cover the commitment to sell, as well as the commitment to buy an asset ${ }^{33}$, and that makes it different from the unilateral promise to sell.

Eventually, apart from the difference noted in the legal literature ${ }^{34}$, there

\footnotetext{
${ }^{31}$ See DEX, cit. (n. 5), p. 858.

${ }^{32}$ See Nicolae, M., Extinctive Prescription (Bucharest, Rosetti Publishing House, 2004), p. 450, note 3.

${ }^{33}$ See STĂnciulescu, L., cit. (n. 6), p. 107.

${ }^{34}$ See Moțiu, F., cit. (n. 6), p. 27.
} 
are further differences between the option agreement regarding the sale contract ${ }^{35}$ and the unilateral promise to sell:

i) as far as the option agreement is concerned, the promised contract (the sale) is being concluded the moment the beneficiary accepts the offer; when it comes to the unilateral promise to sell, the promised contract (the sale) is not being concluded when the beneficiary accepts the offer (to buy), it is only a bilateral promise to sell-buy, obliging the parties involved to subsequently enter into the sale contract; as a result, the provisions of article 1279 (3) (the issuance of a Court order equivalent with the contract) are not applicable for option agreements;

ii) the option agreement and the declaration of acceptance of the beneficiary shall be concluded in the legally stipulated form for the contract the parties are about to enter into (article 1278 (5) RomCC.). As far as the unilateral promise to sell is concerned, the new Civil Code requires no specific form, leading to the conclusion that the promise is consensual;

iii) the option agreement regarding a sales contract related to a given individual item is always accompanied by an inalienability clause, "expressly stipulated by the law" [article 1668 (1)], whereas the inalienability clause is implied in a unilateral promise to sell [article 627 (4)].

Taking into consideration all the above mentioned, we consider that, in the Romanian private law, the option agreement is not a unilateral promise to sell, neither a variety of the unilateral promise to sell, but a contract with an option right.

\section{The option agreement in the Romanian private law and the unilateral} promise to sell in the French legislation.

In the French legal context, the unilateral promise to sell, as a variety of the unilateral promise to enter into a contract, is known as "option agreement". According to the French authors, "the unilateral promise to sell has in view the option granted to the beneficiary for a period of time; either to buy or to revoke the sale. Consequently, the existence of an option differentiates the unilateral promise from the synallagmatic promise. Unlike a policitante, the promisor cannot revoke his promise for as long as it was established. It

${ }^{35}$ Within the meaning of Article 1668 RomCC.: "(1) as far as the option agreement regarding a sales contract related to a given individual item is concerned, the item in question is not to be used between the date the agreement has been made and the date the option is put into practice or, as the case may be, the date of expiry of the option./ (2) When the option agreement refers to real estate rights, the right of option is to be recorded in the real estate register./ (3) The right of option shall be extinguished by default if, until the expiry of the option, no declaration to put into practice the option has been recorded accompanied by the proof that the other party has been notified accordingly". 
is a commitment to sell; it only needs the acceptance of the beneficiary to turn the promise into a sale. The commitment does not involve an obligation to do something, as the sale shall take place without any action from the promisor. The sale takes place in 2 stages: at the time of the promise, it is all done on part of the promisor; at the time the option is put into practice, it is the beneficiary's turn to step in" 36 .

The theory of the French law regarding the promise to sell has a solid legal basis in the provisions of article 1589 (1) of the French Civil Code, according to which: "La promesse de vente vaut vente lorsqu' ily a consentement réciproque des deux parties sur la chose et sur le prix". According to this text, the promise to sell becomes a sale as soon as the two parties agree upon the item to be sold and the price of the item ${ }^{37}$.

On the other hand, based on the provisions of article 1278 RomCC. and of article 1589 (1) of the French Civil Code, the option agreement regarding a sale contract in the Romanian private law is one and the same with the unilateral promise to sell in the French legislation. However, as shown before, the option agreement (in the Romanian Civil law) is not a unilateral promise to sell and has a wider area of application as it basically covers any type of contract, not only the commitment to sell.

11. The unilateral promise to enter into a contract in the Romanian private law and the unilateral promise to enter into a contract in the French legal context.

In the French law, the unilateral promise to enter into a contract is considered to be a very elaborated form of preparatory contract using as model the unilateral promise to sell ${ }^{38}$.

The unilateral promise to enter into a contract is an agreement aiming at establishing the offer of the promisor who fully and permanently agrees to conclude a certain contract, whereas the beneficiary only agrees to choose between accepting and not accepting that offer ${ }^{39}$. The beneficiary of the

\footnotetext{
${ }^{36}$ See Malaurie, P. - Aynès, L. - Gautier, P.-Y., cit. (n. 9), p. 68.

${ }^{37}$ See Code civile, edition 2007, Dalloz, Paris, p. 1616; Malaurie, P. - Aynès, L. Gautier, P.-Y., Les contrats spéciaux (Paris, Cujas, 2001-2002), pp. 114-115.

${ }^{38}$ See BÉnac-Schmidt, F., Le contrat de promesse unilatérale de vente (Paris, L.G.D.J., 1983); Mazeaud, H. et. L. - Chabas, F. Leçons de droit civil, II,1: Obligations. Théorie générale (Paris, Montchrestien, 1998), pp. 128-132; Malinvaud, Ph., Droit des obligations (Paris, Litec, 2003), p. 81; Terré, F. - Simler, Ph. - Lequette, Yv., Droit civil. Les obligations (Paris, Dalloz, 2005), pp. 193-197; Malaurie, P. - AyNÈs, L. - Gautier, P.-Y., cit. (n. 37), pp. 101-115.

${ }^{39}$ See Mousseron, J. M. - Guibal, M. - Mainguy, D., avec la participation du Bureau Fr. Lefebvre et de B. Guéguen, L'avant-contrat (Paris, Edition Fr. Lefebvre, 2001), p. 328.
} 
promise accepts the commitment of the promisor, without undertaking the obligation that he, in his turn, will also permanently enter into that contract; the beneficiary has the right of option, having the freedom to consent or not to the conclusion of that contract ${ }^{40}$.

The authenticity of this promise resides in that the promisor has already expressed his will to enter into that future contract, to the benefit of the beneficiary, so that, in order for the contract to be concluded, the latter needs to give his declaration of will, that is to make an option (to accept the offer). This is to explain that the unilateral promise to enter into a contract is also called "option agreement"

Consequently, in the French law, the effects of the unilateral promise to enter into a contract are the obligation of the promisor to maintain the offer for as long as the option lasts, without any right to revoke it ${ }^{42}$. This comes as an opposition to the theory and practice of the Romanian civil law, according to which the promisor is considered to be the debtor of an obligation to do, namely to enter in the future into a certain contract ${ }^{43}$.

As far as the beneficiary is concerned, the unilateral promise to enter into a contract generates a special right for the beneficiary ("option right"), allowing him to conclude the contract by simply making an option ${ }^{44}$, without the necessity of a later agreement; according to some authors, the option right is a claim ${ }^{45}$, whereas, according to the vast majority, it is a potestative right $^{46}$. The titular of this right is totally free to choose between concluding the contract and the refusal to do so.

The beneficiary preserves his right for the whole period of time expressly or implicitly granted until he can make an option. However, there is a distinction between the legal situation before and after the option has been made ${ }^{47}$. Until accepting the offer, the beneficiary is the titulary of a special right based on which he has the unilateral power to permanently enter into that contract; it is transferable among the living and in case of death, unless

${ }^{40}$ See Pop, L., cit. (n. 15), p. 222.

${ }^{41}$ See Mousseron, J. M. - M. Guibal, M. - Mainguy, D., cit. (n. 39). , p. 328.

${ }^{42}$ Ibidem, p. 340.

${ }^{43}$ See Pop, L., cit. (n. 15), p. 222.

${ }^{44}$ See Schmidt, J., Négociation et conclusion des contrats (ParisDalloz, 1982), p. 269.

${ }^{45}$ See Bénac-Schmidt, F., cit. (n. 38), p. 111.

${ }^{46}$ See NaJjar, I., Le droit d'option à l étude du droit potestatif et de l acte unilatérale (Paris, L.G.D.J., 1967), p. 137 and foll; Malaurie, P. - Aynès, L. - Gautier, P.-Y., cit. (n. 37), p. 103.

${ }^{47}$ See Delebecque, Ph. - Pansier, F. J., Droit des obligations. Contrat et quasicontrat (Paris, Litec, 2003), pp. 62-63; Terré, F. - Simler, Ph. - Lequette, Yv., Cit. (n. 38), pp. 196-197. 
it is persona $e^{48}$. Once the beneficiary has made an option, the contract has been entered into. For example, in case of the unilateral promise to sell an item, the beneficiary becomes as from that moment the holder of the property right, with all the consequences related. In case the option has not been made within the prescribed deadline, the promise is void.

The ability of the promisor to enter into a contract is considered in terms of the moment he made a promise, because he undertakes an obligation then; on the other hand, the ability of the beneficiary to enter into a contract is considered in terms of the date the option is being made ${ }^{49}$.

The promise to enter into a contract is consensual. By exception, should the law provide ad validitatem an authentic document for the definitive contract; the promisor shall give his consent to the conclusion of the promise in authentic form, because it is definitive and irrevocable as from that moment. As far as the beneficiary of the promise is concerned, only his declaration of will shall be made in authentic form as that is the moment that the contract is definitively concluded ${ }^{50}$.

A Romanian author has recently taken over the entire perspective of the French law regarding the unilateral promise to enter into a contract ${ }^{51}$. He narrows down his studies to the unilateral promise to sell ${ }^{52}$; according to him, the unilateral promise to sell is one and the same with the option agreement.

Nonetheless, the Romanian legal literature rejected this point of view. It was shown that: "[...] treated as such in the French law, this institution is wrongly called "promise to sell" because the seller is not obliged to sell, still he is obliged not to sell that item to somebody else since the sale contract can be entered into by the sole will of the buyer, even though the seller would no longer agree to the contract. The institution would be a promise to sell only if the contract were a solemn contract. In our opinion, such a point of view distorts reality because the promissory seller has not agreed to sell the item, he only agreed to enter into the contract at a future time. The solutions adopted in the French law under article 1589 (1) of the French Civil Code

${ }^{48}$ See Mousseron, J. M. - Guibal, M. -Mainguy, D., cit. (n. 39), pp. 347-348.

${ }^{49}$ Ibid., p. 333; Terré, F. - Simler, Ph. - Lequette, Yv., cit. (n. 38), pp. 195 196.

${ }^{50}$ See Schmidt, J., cit. (n. 44), p. 273; Mousseron, J. M. - Guibal, M. -MainGUY, D., cit. (n. 39), pp. 334-335.

${ }^{51}$ See ChIrică, D., cit. (n. 26), p. 148-149.

${ }^{52}$ See CHIRICă, D., The Unilateral Promise to Sell and to Buy, in The Magazine for Commercial Matters, 9 (1999), p. 39 and foll. 
("la promesse de vente vaut vente") - this text has not been taken over by the Romanian legislator- has no solid justification in our law"53.

The Romanian court practice has been non-receptive to this point of view, still preserving the traditional legal regime to the unilateral promise to sell ${ }^{54}$.

The French law, in matters of the promise to sell, is to be found in the provisions of article 1589 (1) of the French Civil Code, according to which: "La promesse de vente vaut vente lorsqu" ily a consentement reciproque des deux parties sur la chose et sur le prix". Thus, according to this text, the promise to sell is a sale since the mutual agreement of the two parties on the item to be sold and on the price ${ }^{55}$. This solution has been widely extended over all types of promise to enter into a contract, be it bilateral or unilateral ${ }^{56}$.

This provision of the French Civil Code has not been taken over in the texts of the 1864 Romanian Civil Code.

Furthermore, the new Romanian civil code either, in force since October the $1^{\text {st }} 2011$, has not taken over the provisions of article 1589 (1) of the French Civil Code. On the contrary, according to article 1279 (2): "For failure to fulfill the promise, the beneficiary is entitled to claim compensation". Consequently, according to the Romanian legislator, the unilateral promise to enter into a contract generates an obligation to do, to enter that contract in the future ${ }^{57}$; this makes it different from the unilateral promise to enter into a contract in the French law.

Likewise, within the meaning of article 1669 (1) RFomCC.: "Considering that one of the parties concluding a bilateral promise to sell refuses, on no solid reasons, to conclude the contract, the other party may ask the Court to issue an order which is equivalent to the contract, should all the other validity conditions be met". These provisions are adequately applicable to the unilateral promise to sell or to buy, as the case may be (article 1669 (3)).

Based on the study of the above mentioned texts, both form the Romanian and from the French legislation, we come to the conclusion that the notion, legal regime and effects of the unilateral promise to enter into

${ }^{53}$ See DeAK, F., Civil Law Treaty. Special Contracts (4 ${ }^{\text {th }}$ edition, updated by Lucian Mihai and Romeo Popescu, Bucharest, Universul Juridic Publishing House, 2006), p. 33.

${ }^{54}$ See Pop, L., cit. (n. 15), p. 224.

${ }^{55}$ See Code civile (Paris, Dalloz, 2007), p. 1616; Malaurie, P. - Aynès, L. - GauTIER, P.-Y., cit. (n. 37), pp. 114-115.

${ }^{56}$ See le Tourneau, Ph., Droit de la responsabilité et des contrats (Paris, Dalloz, 2004-2005), pp. 239-242, 904-905.

${ }^{57}$ See Pop, L., cit. (n. 15), p. 224. 
a contract are legal issues differently regulated and solved in the Romanian private law as compared to the French private law.

\section{Conclusions.}

In the system of the new Romanian civil code, the option agreement is not a unilateral promise to sell, neither a variety of the unilateral promise to sell, it is a contract with an option right. After studying the provisions of article 1278 (Romanian civil code) and of article 1589 (1) of the French Civil Code, the option agreement regarding a sale contract (in the Romanian private law) is one and the same with the unilateral promise to sell (French law). However, in the Romanian civil law, the notion, legal regime and effects of the unilateral promise to enter into a contract are legal issues differently regulated and solved as compared to the unilateral promise to enter into a contract existing in the French private law.

\section{BIBLIOGRAPHY}

Albu, I., Civil law. The Contract and Contractual Obligation (Cluj-Napoca, Dacia Publishing House, 1994).

Andrei, D. - Ronea Avram, M. - Dumitrache, B., The Obligations of the Promisor Seller and their Enforcement, in the magazine Dreptul, 3 (1995).

BÂrSan, C., Legal Regime of Real Estate Assets (Bucharest, Scientific and Encyclopedic Publishing House, 1983).

BÉnAC-SChmidt, F., Le contrat de promesse unilatérale de vente (Paris, L.G.D.J., 1983).

BOyer, L., Les promesses synallagmatiques de vente, in Revue Trimestrelle de Droit Civil, 47 (1949).

Chelaru, E., Aspects Related to the Legal Circulation of Privately-Owned Land, in the magazine Dreptul, 9 (1993).

Chirică, D., Civil Law Treaty. Special Contracts, I: Sale and Exchange (Bucharest, C.H.Beck Publishing House, 2008).

Chirică, D., Civil Law Treaty. Special Contracts, I: Sale and Exchange (Bucharest, C.H.Beck Publishing House, 2008).

Chirică, D., Civil Law, Special Contracts (Bucharest, Lumina Lex Publishing House, 1997).

CHIRICĂ, D., The Consequences of the Post-Revolutionary Legislative Amendments upon the Circulation of Privately-Owned Land, in the magazine Dreptul, 6 (1991).

CHIRICĂ, D., The Unilateral Promise to Sell and to Buy, in The Magazine for Commercial Matters, 9 (1999).

Deak, F., Civil Law Treaty. Special Contracts ( $3^{\text {rd }}$ edition, updated and completed, Bucharest, Universul Juridic Publishing House, 2001).

Deak, F., Civil Law Treaty. Special Contracts ( $4^{\text {th }}$ edition, updated by Lucian Mihai and Romeo Popescu, Bucharest, Universul Juridic Publishing House, 2006). 
Delebecque, Ph. - Pansier, F. J., Droit des obligations. Contrat et quasi-contrat (Paris, Litec, 2003).

$\operatorname{DEX}\left(2^{\text {nd }}\right.$ edition, Bucharest, Univers Encyclopedic Publishing House, 1996).

DîrJan, T., The Pre-Existing Sale Contract, in the magazine Dreptul, 3 (2000).

Florescu, D., Civil contracts (Bucharest, Universul Juridic Publishing House, 2011).

Ionașcu, A. -Mureșan, M. - Costin, M ., The Contribution of Case-Law to the Development of the Principles of the Romanian Civil Law (Bucharest, The Publishing House of the Academy, vol. I, 1973, vol. 2, 1978).

Le Tourneau, Ph., Droit de la responsabilité et des contrats (Paris, Dalloz, 20042005).

Lulă, I. - Hantea, D., Debates on the Synallagmatic Promise to Sell-Buy Land, in the magazine Dreptul, 9 (2003).

Malaurie, P. - Aynès, L. - Gautier, P.-Y., Les contrats spéciaux (Paris, Cujas, 20012002).

Malaurie, P. - Aynès, L. - Gautier, P.-Y., Special contracts (Bucharest, Wolters Kluwer Publishing House, 2009).

Malinvaud, Ph., Droit des obligations (Paris, Litec, 2003).

Mazeaud, H. et. L. - Chabas, F. Leçons de droit civil, II,1: Obligations. Théorie générale (Paris, Montchrestien, 1998).

Minuță, I. G., Collection of Legal Cases in Civil Matters of the High Court and of other Courts in the period of Time 1969-1975 (Bucharest, Scientific and Encyclopedic Publishing, 1976).

Moțıu, F., Civil Contracts in the New Civil Code (Bucharest, Wolters Kluwer Publishing House, 2010).

Mousseron, J. M. - Guibal, M. - Mainguy, D., avec la participation du Bureau Fr. Lefebvre et de B. Guéguen, L'avant-contrat (Paris, Edition Fr. Lefebvre, 2001).

Mureșan, M., Civil Law Dictionary, by M. Costin, M. Mureșan, V. Ursa (Bucharest, Scientific and Encyclopedic Publishing House, 1988).

Mureșan, M., Civil Law. Special Contracts. Academic Courses (Cluj-Napoca, Cordial Lex Publishing House, 1999).

Mureşan, M., Consequences of the Repealed Law 58/1974 upon the Promissory Contracts to Sell Real Estate Assets, in the magazine Dreptul, 7-8 (1991).

NaJjar, I., Le droit d'option à l' étude du droit potestatif et de l'acte unilatérale (Paris, L.G.D.J., 1967).

NaJjar, I., Le droit d'option à létude du droit potestatif et de lacte unilatérale (Paris, L.G.D.J., 1967).

Nicolae, M., Extinctive Prescription (Bucharest, Rosetti Publishing House, 2004).

Nicolae, M., Extinctive Prescription (Bucharest, Rosetti Publishing House, 2004).

Pătulea, V., The Enforcement of Civil Law Related to the Alienation of Real Estate Assets, in the magazine Dreptul, 11 (1992).

Pop, L., Civil Law Treaty. Obligations, II: The Contract (Bucharest, Universul Juridic Publishing House, 2009).

Popa, I. - Dumitrache, B., The Pre-Existing Sale Contract and the Synallagmatic Promise to Sell-Buy.

Safta-Romano, E., Civil Law. Obligations (Focşani, Neuron Publishing House, 1994).

Safta-Romano, E., Legal Regime of Promissory Contracts in Relation to the Alienation 
of Real Estate Assets After the Repealing of Decree Nr. 144/1958, in the magazine Dreptul, 9 (1993).

Schmidt, J., Négociation et conclusion des contrats (ParisDalloz, 1982).

Stănciulescu, L., Civil Law Lectures. Contracts (Bucharest, Hamangiu Publishing House, 2012).

Terré, F. - Simler, Ph. - Lequette, Yv., Droit civil. Les obligations (Paris, Dalloz, 2005).

Turianu, C., Special Civil Contracts. Established Case-Law (Bucharest, All Beck Publishing House, 2000).

Urs, I., Civil Law. Special Contracts, I: Sale, Exchange and Donation (Cluj-Napoca, Risoprint Publishing House, 2010).

Vurdea, I. C. Bîrsan, C. - Stoica, V., The Evolution of Legislation Regarding the Circulation of Buildings, in the magazine Dreptul, 6 (1990). 